\title{
Retroperitoneal tumor: giant cavernous hemangioma - case presentation and literature review
}

\author{
Jacek Zielinski ${ }^{1}$, Ireneusz Haponiuk ${ }^{2}$, Radoslaw Jaworski², Rafal Peksa ${ }^{3}$, Ninela Irga-Jaworska ${ }^{4}$, \\ Janusz Jaskiewicz ${ }^{1}$ \\ ${ }^{1}$ Department of Surgical Oncology, Medical University of Gdansk, Gdansk, Poland \\ ${ }^{2}$ Department of Pediatric Cardiac Surgery, Mikolaj Kopernik Hospital, Gdansk, Poland \\ ${ }^{3}$ Department of Pathology, Medical University of Gdansk, Gdansk, Poland \\ ${ }^{4}$ Department of Pediatrics, Hematology and Endocrinology, Medical University of Gdansk, Gdansk, Poland
}

Kardiochirurgia i Torakochirurgia Polska 2016; 13 (4): 375-379

\begin{abstract}
Retroperitoneal hemangiomas are very rare. This paper presents the case of a 71-year-old female patient with giant cavernous hemangioma of the retroperitoneum who underwent surgical treatment for abdominal pain and left lower limb edema. Interventional staged treatment with percutaneous transcatheter arterial embolization prior to surgery was considered. Radical resection of the tumor was performed, which caused the symptoms to abate. Additionally a literature review of cases involving cavernous hemangioma in the retroperitoneal space is presented. No description of retroperitoneal cavernous hemangioma originating from the bowel was found in the analyzed reports.
\end{abstract}

Key words: cavernous hemangioma, retroperitoneal tumors, retroperitoneal hemangioma, interventional treatment, surgery.

\section{Introduction}

Primary retroperitoneal tumors (PRTs) of vascular origin are a diverse group of rare abdominal neoplasms, both benign and malignant [1]. The most frequent malignant tumors are liposarcoma and leiomyosarcoma, while the most often found benign tumors are lipoma, leiomyoma and cavernous hemangioma [2-5]. Hemangiomas are a group of neoplasms originating from vascular tissue where benign tumors prevail. Among these capillary hemangioma, cavernous hemangioma, racemous hemangioma, angioleiomyoma and hemangiopericytoma are most frequent. Malignant hemangiomas are rare. Cavernous hemangiomas most frequently occur in the liver. Other described localizations are skin, muscles, bones, central nervous system and retroperitoneal organs (intestines, kidneys, adrenal glands, urinary bladder, uterus) [6-16].

An interventional staged therapy is becoming more popular with the aim of reducing the diameter of the main

\section{Streszczenie}

Naczyniaki przestrzeni zaotrzewnowej są bardzo rzadkie. W niniejszej pracy przedstawiono przypadek 71-letniej pacjentki z gigantycznym naczyniakiem jamistym przestrzeni zaotrzewnowej, która została poddana leczeniu chirurgicznemu z powodu bólu brzucha i obrzęku lewej kończyny dolnej. Rozważano przeprowadzenie interwencyjnego leczenia etapowego poprzedzonego przezcewnikową embolizacją tętnicy. Wykonano radykalną resekcję guza, co spowodowało ustąpienie objawów. Dodatkowo w pracy przedstawiono przegląd przypadków naczyniaków jamistych w przestrzeni zaotrzewnowej. W przeanalizowanych pracach nie odnaleziono opisu naczyniaka jamistego w przestrzeni zaotrzewnowej, który pochodzitby z jelita.

Słowa kluczowe: naczyniak jamisty, guzy przestrzeni zaotrzewnowej, naczyniak przestrzeni zaotrzewnowej, leczenie interwencyjne, chirurgia.

hemangioma, especially that surrounded with diffuse hemangiomatosis [17]. Successful combination of transcatheter arterial embolization (TAE) prior to the surgery of cavernous hemangioma of the liver was reported recently [18]. Nevertheless, the treatment of choice for primary retroperitoneal tumors is still radical surgical resection that leads to recovery. Surgical techniques used for treatment of PRTs are: open procedures, laparoscopy, surgical endoscopy and percutaneous radiofrequency ablation $[8,19]$.

The present case is a patient with giant retroperitoneal cavernous hemangioma originating from the ilium with atypical clinical course who was referred for surgical treatment.

\section{Case report}

A 71-year-old female patient was referred to the Department of Surgical Oncology with a giant retroperitoneal tumor located in the left iliac fossa. The patient discovered the abdominal tumor 15 years earlier, but as it did not 


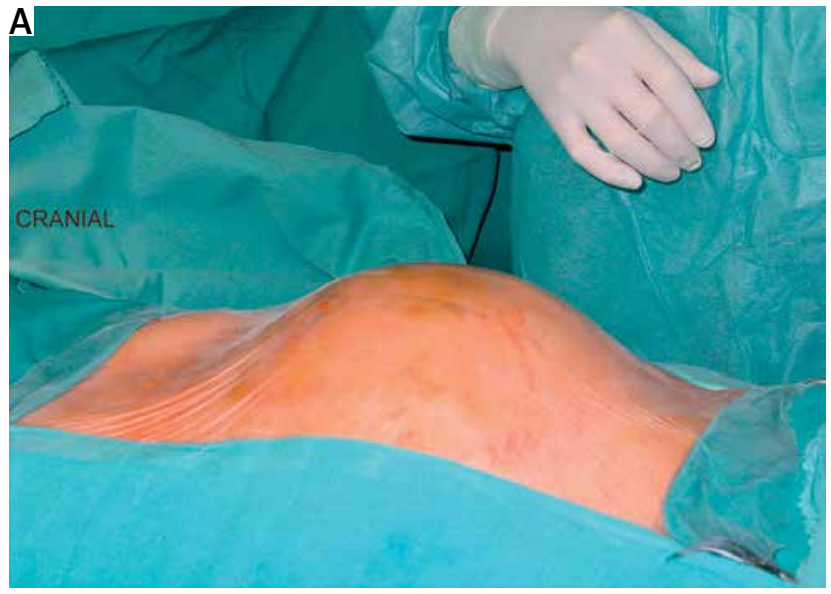

Fig. 1. A - Giant abdominal mass filling abdominal cavity. B - Computed tomography scan revealing a large, left-sided retroperitoneal mass

cause any problems she refused to seek medical help. No symptoms from the intestinal or urinary tract were present. Several months prior to admission to the department the first symptoms appeared: left lower limb edema, exertional dyspnea, abdominal distension and anemia with pallor and lowered hemoglobin level. Physical examination revealed a large, skin modeling, nonpulsatile mass in the left iliac fossa (Fig. $1 \mathrm{~A}$ ).

When abdominal contrast-enhanced computed tomography $(\mathrm{CT})$ was performed, a tumor $20 \times 17 \times 18 \mathrm{~cm}$ in diameter lying on the iliac ala was found (Fig. 1 B). The tumor did not meet radiological criteria for vascular tumors. No lesions in the liver were found. Infiltration of retroperitoneal organs and structures could not be excluded. Chest $X$-ray did not reveal any abnormalities within the thorax. An ultrasonography-guided fine needle biopsy was performed, revealing blood cells with necrotic masses and connective tissue which prevented precise diagnosis. Blood laboratory findings were: anemia $(\mathrm{Hb} 8.8 \mathrm{~g} / \mathrm{dl})$, elevated white blood cell count $(21.81 \mathrm{G} / \mathrm{l})$ and high C-reactive protein level (100.8 mg/l).

Because of uncertainties regarding the histological type of the tumor, escalation of abdominal pain and left lower limb edema in recent weeks and the patient's strong willingness to remove the tumor, the decision to perform laparotomy was made (Figs. $2 \mathrm{~A}, \mathrm{~B}$ ).

During the surgery a large mass on the ala was found. There were no signs of infiltration of neighboring organs, and the sigmoid colon was tight on the tumor. After separating the sigmoid and identification of the left ureter and iliac vessels the tumor was removed. No other organs were hurt or resected. Massive damage to the internal surface of the ala was found in the place where the tumor grew. Hemostasis was performed and the surface marked with titan clips. The postoperative period was uncomplicated. The patient was discharged from the hospital on postoperative day 5 .

Pathologic examination showed a tumor $20 \times 19 \times$ $16 \mathrm{~cm}$ in diameter, weighing $3000 \mathrm{~g}$ (Fig. 2 C). On $1 / 3$ of its

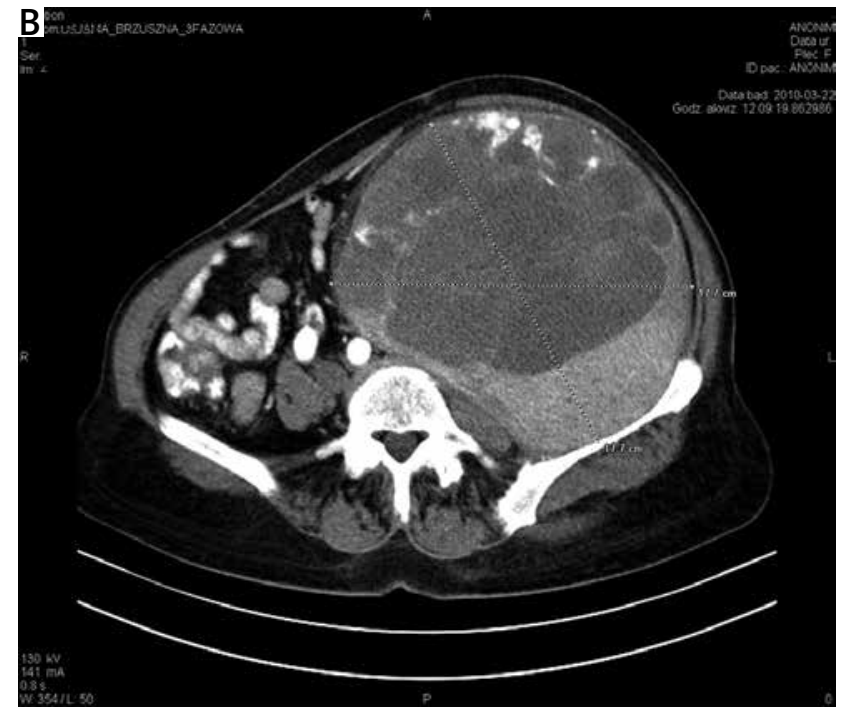

surface a peduncle connecting the tumor to the ala was found. The tumor had microscopic features of vascular neoplasm - cavernous hemangioma. Histochemically the cells lining the lacunae were stained positively by markers for CD34 (Figs. $3 \mathrm{~A}, \mathrm{~B}$ ).

The postoperative follow-up is 3 years. Within this time limb edema and other symptoms gradually abated.

\section{Discussion}

Primary retroperitoneal tumors are usually diagnosed late, when the disease is advanced. This is caused by its initially symptomless course and therefore delayed presentation to a physician.

The most frequent symptoms of retroperitoneal tumors are non-specific abdominal pain (51.8\%) and abdominal distension (18.7\%). Less frequent symptoms include constipation (8\%), fever (8\%), dysuria (4.3\%), lower limb edema (6.5\%), weight loss and cachexia (5\%) [2]. The time of these symptoms' occurrence varies from several months for sarcomas to years for benign tumors. Patients usually visit a physician when they discover a pathological mass in the abdomen (60.4\%) [1]. In the present case her first symptoms (abdominal distension and limb edema) occurred 15 years after discovering the tumor.

On CT images retroperitoneal tumors present as heterogeneous pathological masses with hypoechogenic areas corresponding to necrotic zones in the tumor [1]. The giant tumor mass causes displacement of adjacent organs. Usually their infiltration is hard to exclude. Similar manifestations occurred in the present case.

We considered an interventional staged therapy with TAE for its possible advantage of reduction of the diameter of the main tumor mass, and surrounding diffuse hemangiomatosis, which was reported in the case of cavernous hemangioma of the liver [18]. The age of the patient with possible diffuse arteriosclerosis and the necessity to resect the symptomatic tumor were the arguments to abandon the percutaneous option. 

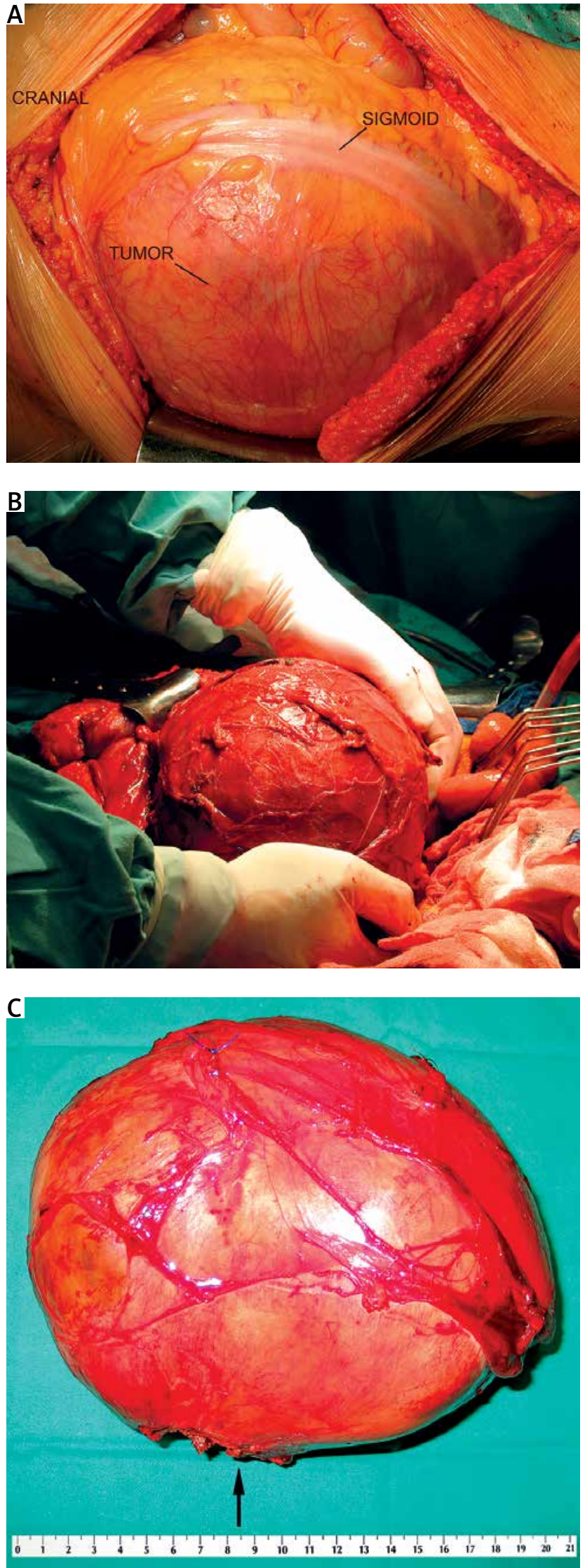

Fig. 2. A - Giant tumor with sigmoid colon tight on it. B - Intraoperative view. $\mathbf{C}$ - The tumor after resection (arrow - peduncle connecting the tumor to the ala)
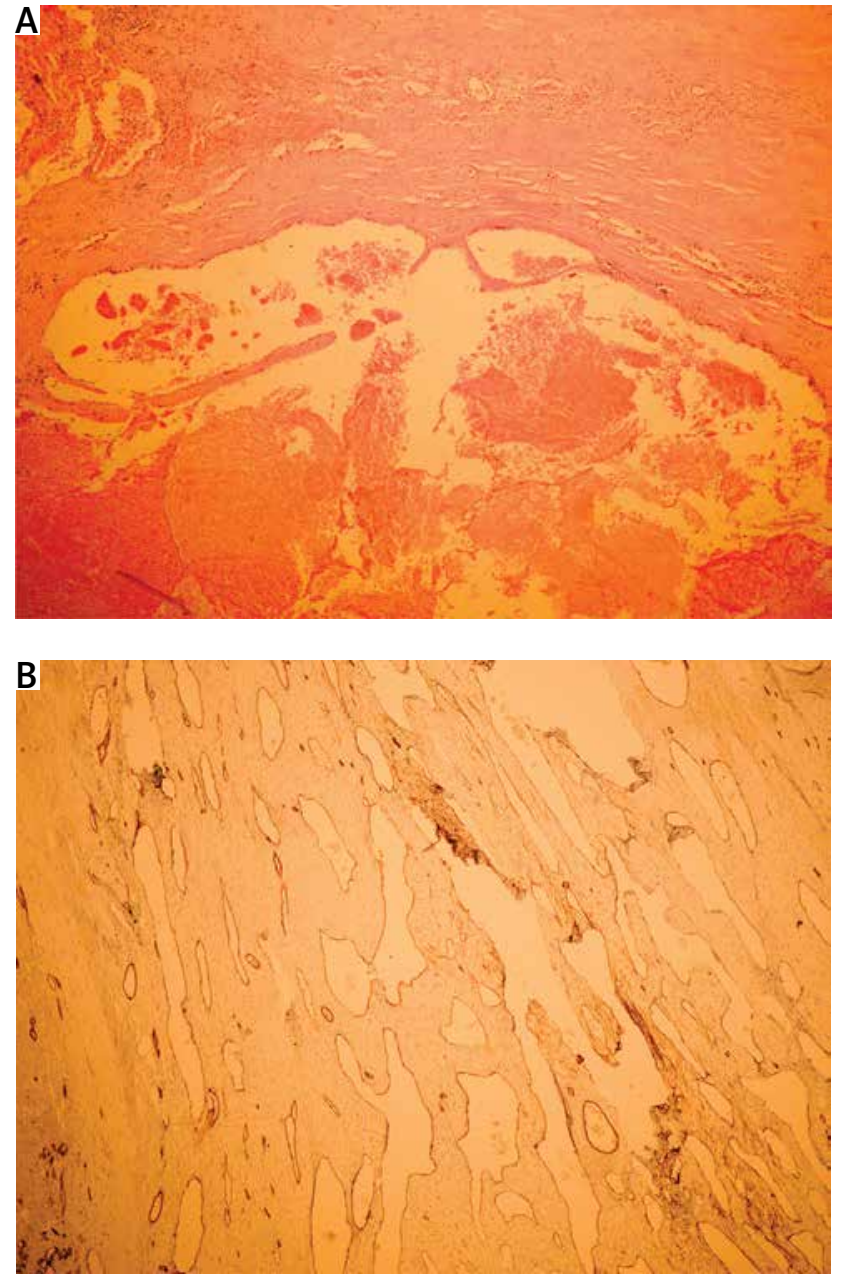

Fig. 3. A - Microscopic image with H\&E (enlargement 10x). Diag. Hemangioma cavernosum. Large vascular spaces separated by scant connective tissue stroma H\&E (enlargement 10x). B - Microscopic image with histochemical examination (enlargement 10x). Diag. Hemangioma cavernosum. Staining with markers for CD34 confirm an endothelial origin of the cells lining the lacunae

Radical resection remains the treatment of choice for cavernous hemangioma. However, one can find publications on treatment of hepatic cavernous hemangioma with percutaneous radiofrequency ablation [19]. In the present case the size and localization of the tumor and urgent necessity made the operation a high-risk procedure with possibility of resecting vital structures, such as the sigmoid colon or ureter.

In the present case the long-term history of abdominal tumor indicated a benign tumor, while radiological and clinical findings suggested malignant disease. The literature review shows that in differential diagnosis of giant abdominal tumors, rare benign neoplasms should be considered in every case. Radical surgical resection resulted in full recovery in our patient, which corresponds to commonly found conclusions despite the huge diameters and the origin of retroperitoneal tumors [20, 21].

In the literature reports we found only 15 cases of retroperitoneal cavernous hemangiomas in kidneys, adrenal 
Tab. I. Literature review of retroperitoneal cavernous haemangiomas

\begin{tabular}{|c|c|c|c|c|c|c|c|c|c|}
\hline \multirow{3}{*}{ Author } & \multirow{3}{*}{$\begin{array}{l}\text { Number } \\
\text { of cases }\end{array}$} & \multirow{3}{*}{ Affected organ } & \multicolumn{7}{|c|}{ Symptoms } \\
\hline & & & \multirow[b]{2}{*}{$\begin{array}{l}\text { Abdomi- } \\
\text { nal pain }\end{array}$} & \multirow[b]{2}{*}{$\begin{array}{l}\text { Palpable } \\
\text { tumor }\end{array}$} & \multicolumn{4}{|c|}{ Bleeding } & \multirow[b]{2}{*}{ Anemia } \\
\hline & & & & & $\begin{array}{c}\text { Gastroin- } \\
\text { testinal } \\
\text { tract }\end{array}$ & $\begin{array}{c}\text { Urinary } \\
\text { tract }\end{array}$ & $\begin{array}{c}\text { Retrope- } \\
\text { ritoneal } \\
\text { space }\end{array}$ & Genitals & \\
\hline Forbes [6] & 1 & Adrenal gland & - & - & - & - & + & - & - \\
\hline Heis [7] & 1 & Adrenal gland & + & + & - & - & - & - & - \\
\hline Telem [8] & 1 & Adrenal gland & + & - & - & - & - & - & - \\
\hline \multirow{3}{*}{ Lee [9] } & \multirow{3}{*}{3} & Kidney & + & - & - & + & - & - & - \\
\hline & & Kidney & + & - & - & + & - & - & - \\
\hline & & Kidney & + & - & - & - & - & - & - \\
\hline Zhao [10] & 1 & Kidney & - & + & - & + & - & - & - \\
\hline Mahdavi [11] & 1 & Urinary bladder & - & - & + & - & - & - & + \\
\hline Bromage [12] & 1 & Urinary bladder & + & - & + & - & - & - & - \\
\hline Benjamin [13] & 1 & Uterus & - & - & - & - & - & + & - \\
\hline Hervias [14] & 1 & Rectum* & - & + & - & - & - & - & - \\
\hline Kaiser [15] & 1 & Rectum* & - & - & + & - & - & - & - \\
\hline Ohkura [17] & 1 & Glisson's capsule* & + & + & - & - & - & - & - \\
\hline Hang [20] & 1 & Primary & - & - & - & - & - & - & - \\
\hline Galea [21] & 1 & Adrenal gland & + & + & - & - & - & - & - \\
\hline Our case & 1 & Ilium & + & + & - & - & - & - & + \\
\hline Total & 16 & - & $\begin{array}{c}9 \\
56.2 \%\end{array}$ & $\begin{array}{c}6 \\
37.5 \%\end{array}$ & $\begin{array}{c}3 \\
18.7 \%\end{array}$ & $\begin{array}{c}3 \\
18.7 \%\end{array}$ & $\begin{array}{c}1 \\
6.2 \%\end{array}$ & $\begin{array}{c}1 \\
6.2 \%\end{array}$ & $\begin{array}{c}2 \\
12.5 \%\end{array}$ \\
\hline
\end{tabular}

*Retroperitoneal localization.

glands, urinary bladder, uterus and the retroperitoneal part of the rectum [6-15]. However, no description of cavernous hemangioma of the ilium was found; therefore our report seems to be a unique contribution to contemporary knowledge (Tab. I).

\section{Conclusions}

Because of their initially symptomless course, primary retroperitoneal tumors are usually diagnosed in an advanced stage of the disease, which is the reason for many uncertainties regarding safe surgical resection. Radical surgical resection remains the treatment of choice for primary retroperitoneal cavernous hemangiomas, although the decision of performing such operations should be taken after thorough analysis of indications (escalation of symptoms) and contraindications (risk of damaging vital retroperitoneal organs with massive bleeding).

\section{Acknowledgments}

The authors thank Dr Pawel Kabata for his great support in preparation of this manuscript.

\section{Disclosure}

Authors report no conflict of interest.

\section{References}

1. Xu YH, Guo KJ, Guo RX, Ge CL, Tian YL, He SG. Surgical management of 143 patients with adult primary retroperitoneal tumor. World J Gastroenterol 2007; 13: 2619-2621.

2. Keyzer-Dekker CM, Houtkamp RG, Peterse JL, Van Coevorden F. Adult pelvic sarcomas: a heterogeneous collection of sarcomas? Sarcoma 2004; 8: 19-24.

3. Ulu EM, Kirbaş I, Töre HG, Başaran C, Oztürk A, Güven G, Karadeli E, Coşkun M. Extraperitoneal pelvic myolipoma. Diagn Interv Radiol 2001; 16: 227-231.

4. Martinez CAR, Palma RT, Waisberg J. Giant retroperitoneal lipoma: a case report. Arq Gastroenterol 2003; 40: 251-255.

5. Herrera-Gómez A, Ortega-Gutiérrez C, Betancourt AM, Luna-Ortiz K. Giant retroperitoneal liposarcoma. World J Surg Oncol 2008; 6: 115.

6. Forbes TL. Retroperitoneal haemorrhage secondary to a ruptured cavernous haemangioma. Can J Surg 2005; 48: 78-79.

7. Heis HA, Bani-Hani KE, Bani-Hani BK. Adrenal cavernous haemangioma. Singapore Med J Case Report 2008; 49: 236-237.

8. Telem DA, Nguyen SQ, Chin EH, Weber K, Divino CM. Laparoscopic resection of giant adrenal cavernous hemangioma. J Soc Laparoendosc Surg 2009; 13: 260-262.

9. Lee HS, Koh BH, Kim JW, Kim YS, Rhim HC, Cho OK, Hahm CK, Woo YN, Park $\mathrm{MH}$. Radiologic findings of renal hemangioma: report of three cases. Korean J Radiol 2000; 1: 60-63.

10. Zhao X, Zhang J, Zhong Z, Koh CJ, Xie HW, Hardy BE. Large renal cavernous haemangioma with renal thrombosis: case report and review of literature. Urology 2009; 73: 443 e1-3.

11. Mahdavi R, Rahmani M. Cavernous hemangioma of the bladder. Urology J 2004; 1: 259-262.

12. Bromage SJ, Chan L, Collins RL. Ultrasound guided location and resection of a suburothelial cavernous haemangioma of the bladder. Br J Radiol 2007; 80: $113-114$. 
13. Benjamin MA, Yaakub HR, Telesinghe $\mathrm{P}$, Kafeel G. A rare case of abnormal uterine bleeding caused by cavernous haemangioma: a case report. J Med Case Reports 2010; 4: 136.

14. Hervías D, Turrión JP, Herrera M, Navajas León J, Pajares Villarroya R, Manceńido N, Castillo P, Segura JM. Diffuse cavernous haemangioma of the rectum: an atypical cause of rectal bleeding. Rev Esp Enferm Dig 2004; 96: 346-352.

15. Kaiser AM, Spanos C. An unusual cause of rectal bleeding. B J Radiol 2005; 78: 373-375

16. Selim H, Selim A, Khachemoune A, Metwally SA. Use of slerosing agent in the management of oral and perioral hamengiomas: review and case reports. Med Sci Monit 2007; 13: 114-119.

17. Ohkura Y, Hashimoto M, Lee S, Sasaki K, Matsuda M, Watanabe G. Right hepatectomy for giant cavernous hemangioma with diffuse hemangiomatosis around Glisson's capsule. World J Gastroenterol 2014; 20: 8312-8316.
18. Kayan M, Cetin M, Aktas AR, Yilmaz O, Ceylan E, Eroglu HE. Pre-operative arterial embolization of symptomatic giant hemangioma of the liver. Prague Med Rep 2012; 113: 166-171.

19. Tak WY, Park SY, Jeon SW, Cho CM, Kweon YO, Kim Sk, Choi YH, Chung JM. UItrasonography-guided percutaneous radiofrequency ablation for treatment of a huge symtomatic hepatic cavernous hemangioma. J Clin Gastroentero 2006; 40: 167-170.

20. Hang H, Zunguo D, Sijie H, Lie Y, Feng Y, Yang D, Ji L, Yongian J, Chen J, Deliang F. Adult primary retroperitoneal cavernous hemangioma: a case report. World J Surg Oncol 2012; 10: 261-265.

21. Galea N, Noce V, Ciolina F, Liberali S, Francone M. Giant adrenal cavernous hemangioma: a rare abdominal mass. Urology 2013; 82: e3-e4. 